Section Editor

Mitchell S.V. Elkind, MD, MS

Ajaykumar Morani, MD Hemant Parmar, MD Mohannad Ibrahim, MD

Correspondence \& reprin requests to Dr. Morani: ajaycmorani@yahoo.com

\section{Teaching NeuroImages: Sequential MRI of the pituitary in Sheehan syndrome}
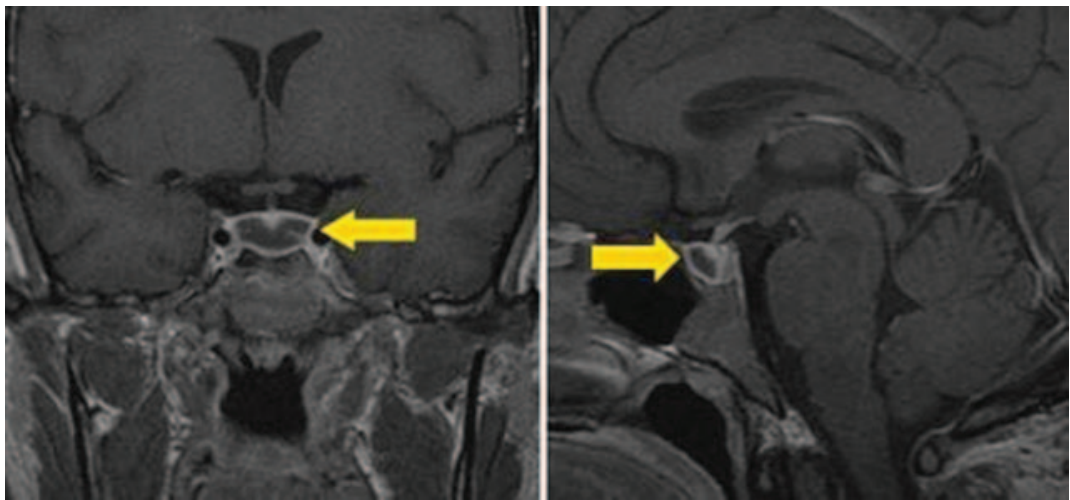

Coronal and sagittal postcontrast T1-weighted spin-echo images show an enlarged pituitary with rim enhancement and no internal enhancement (arrows). Findings are suggestive of nonhemorrhagic pituitary infarct, i.e., Sheehan syndrome.

\section{Figure 2 Temporal evolution of the pituitary gland in Sheehan syndrome}
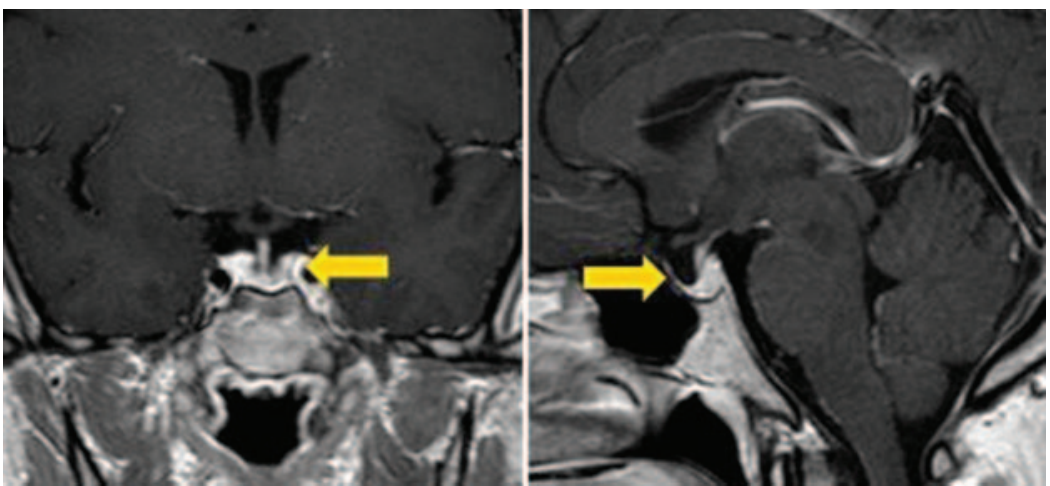

Coronal and sagittal postcontrast T1-weighted spin-echo images show atrophy of the anterior pituitary gland (arrows) on follow-up MRI 1 year later.

A 32-year-woman with postpartum bleeding was unable to lactate. Investigations revealed hypocortisolism and hypoprolactinemia. MRI revealed an enlarged cystic pituitary suspicious for infarct. Sheehan syndrome is a clinical state of panhypopituitarism resulting from pituitary infarction after a peripartum hypotensive episode. ${ }^{1,2}$ In the acute phase, the pituitary is enlarged with homogeneous T1-weighted hypointensity and T2-weighted hyperintensity with rim enhancement (figure 1). Sometimes infarcted areas are interspersed with perfused tissue, causing irregular pituitary enhancement. ${ }^{1}$ It is later followed by anterior pituitary atrophy (figure 2). ${ }^{1,2}$ The differential is lymphocytic hypophysitis, which may show a similar cystic focus in the pituitary in $5 \%$ of patients with subsequent atrophy. ${ }^{1}$

\section{AUTHOR CONTRIBUTIONS}

Dr. Morani: drafting/revising the manuscript, study concept or design, acquisition of data. Dr. Parmar: drafting/revising the manuscript, analysis or interpretation of data, study supervision. Dr. Ibrahim: study concept or design, acquisition of data.

\section{REFERENCES}

1. Kaplun J, Fratila C, Ferenczi A, et al. Sequential pituitary MR imaging in Sheehan syndrome: report of 2 cases. AJNR 2008;29(suppl 5):941-943.

2. Zak IT, Dulai HS, Kish KK. Imaging of neurologic disorders associated with pregnancy and the postpartum period. Radiographics 2007;27(suppl 1):95-108. 


\section{Neurology}

\section{Teaching NeuroImages: Sequential MRI of the pituitary in Sheehan syndrome}

Ajaykumar Morani, Hemant Parmar and Mohannad Ibrahim

Neurology 2012;78; 3

DOI 10.1212/WNL.0b013e31823ed07d

This information is current as of December 26, 2011

Updated Information \&

Services

References

Permissions \& Licensing

Reprints including high resolution figures, can be found at:

http://n.neurology.org/content/78/1/e3.full

This article cites 2 articles, 1 of which you can access for free at: http://n.neurology.org/content/78/1/e3.full\#ref-list-1

Information about reproducing this article in parts (figures,tables) or in its entirety can be found online at:

http://www.neurology.org/about/about_the_journal\#permissions

Information about ordering reprints can be found online: http://n.neurology.org/subscribers/advertise

Neurology ${ }^{\circledR}$ is the official journal of the American Academy of Neurology. Published continuously since 1951, it is now a weekly with 48 issues per year. Copyright Copyright (? 2012 by AAN Enterprises, Inc.. All rights reserved. Print ISSN: 0028-3878. Online ISSN: 1526-632X.

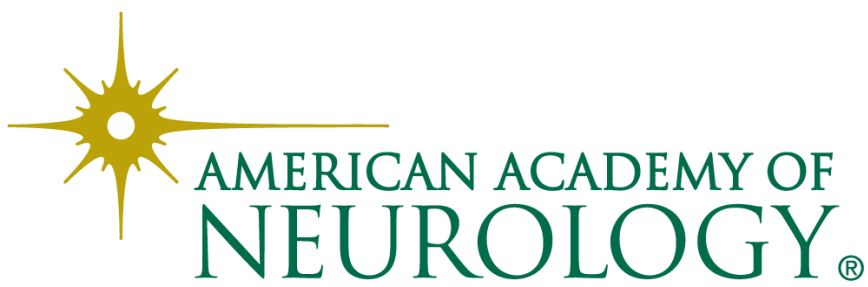

